\title{
Does the offence of blasphemy have a future under the South African constitution?
}

\author{
Kobus van Rooyen \\ University of Pretoria
}

\begin{abstract}
This article reflects upon the question of whether the offence of blasphemy is valid in terms of the Constitution of the Republic which guarantees equal protection and freedom of religion, opinion, conscience and belief. Blasphemy protects only the Christian and Judaic perceptions of God. Would a Muslim, for example, not be entitled to protection under a broadened offence? And does the offence not discriminate against religions not protected by blasphemy? The author contends that Parliament has a duty to either broaden the scope of blasphemy or to scrap the offence. He is, however, of the view that the offence is not, in itself, unconstitutional and that Parliament should, given the sensitivities in this sphere, not scrap the offence but rather protect the religious convictions of all sections of the population.
\end{abstract}

\section{INTRODUCTION}

Chapter 3 of the interim Constitution of the Republic of South Africa guarantees freedom of religion and also guarantees that no person shall be unfairly discriminated against on grounds of, for example, religion, conscience or belief.

It is trite that the offence of blasphemy only protects Christian and Judaic perceptions of God (Publications Control Board v Gallo [Africa] Ltd 1975[3] SA 665[A] 671; Burchell \& Milton 1991:556). The question which arises is whether the offence could withstand constitutional scrutiny. One is inclined to almost immediately conclude that the offence, given its limited sphere of protection, would be found to be invalid. However, two decisions of the European Commission of Human Rights have concluded differently. One could argue that the Commission's decisions should not readily be accepted since they allow for a margin of appreciation for the national legal systems which fall under its jurisdiction. Yet, both these decisions concentrate on the fact that the offence of blasphemy in England does not discriminate against the accused on grounds of, for example, gender, sexual orientation or belief. This approach gives a new perspective to the matter: say, for example, assault could per definition only be committed against women; would an accused be able to argue that the offence is unconstitu- 
tional since the offence of assault discriminates by only protecting women? This does not, of course, mean that Parliament should not take steps in broadening the scope of religious protection in the light of the equal protection guaranteed by the Constitution. Conversely it could be argued that freedom of religion, conscience, belief and opinion, necessitates the repeal of blasphemy and that the State has no compelling interest in condemning people for what they believe and express in this regard. Is religious peace dependent on the protection of religious feelings as such? Laws which protect the peaceful exercise of religious rights, for example by outlawing disturbance of religious ceremony or attendance, would be understandable since the maintenance of public order would possibly be endangered. But are religious feelings as such an object for protection?

\section{SHOULD RELIGIOUS FEELINGS BE PROTECTED}

The approach of the Commission of Human Rights has been that religious feelings may be protected by national systems under its supervision. In 1994 the Court (Otto Preminger Institut v Austria [11/1993/406/485] [22 Sept 1994]) itself recognised this by finding that Austrian authorities had not contravened the freedom of expression guarantee in its convention, by having seized and declared forfeited a film which, according to the Austrian Courts, led to a 'justified indignation' by Roman Catholics in the Tyrol, $87 \%$ of the populace being Roman Catholics. Although the reasoning of the Court could be criticised, the fact remains that recognition is given to the protection of religious feelings, also in the sphere of a film screened in a theatre, which had advertised the nature of the film so that the public could come to an informed choice before attending.

The latter aspect is, to my mind, the crux of the problem: should a state recognise religious (or moral) sensitivities even when people are not confronted with the material and they can come to an informed choice not to attend or not to read? It is submitted that the source of the outrage amongst non-viewers or non-readers is often the fact that the State, which they expect to either be religious itself or assist them in wiping out forces which confront their religion or portray their religion incorrectly or amount to sin or evil according to the precepts of their religion, has allowed a film to be screened or a book to be distributed. In the background looms the idea of the religious state, a concept which is becoming increasingly foreign to Western thinking. The judgment of the European Court of Human Rights in the Kokkinakis case, (Kokkinakis v Greece [25/5/1933] [Series A No 260]) where it was held that the Greek offence of proselytism is in conflict with the freedom of religion clause in its Convention of Human Rights illustrates this point well (the Greek Constitution provided for freedom of religion but 
prohibited proselytism and all other activities directed against the dominant religion, that of the Christian Eastern Orthodox Church. In the current Constitution this prohibition is extended to all religions).

\section{TWO DECISIONS OF THE EUROPEAN COMMISSION OF HUMAN RIGHTS}

Returning to the issue of constitutionality of blasphemy, the facts of the two cases before the European Commission of Human Rights are now dealt with.

The first is Gay News Ltd and Lemon v United Kingdom (5 E H R R 123, 1982). The applicants were the publishers of a magazine called Gay News, the readership of which consisted mainly of homosexuals. One of the issues, published in June 1976, carried a poem entitled 'The love that dares to speak its name', which, according to the headnote of the House of Lords' decision ( $\mathrm{R}$ v Lemon [1979] AC 435) purported to describe in explicit detail acts of sodomy and fellatio with the body of Christ immediately after his death and ascribed to him during his lifetime promiscuous homosexual practices with the Apostles and other men. The poem was accompanied by a drawing illustrating its subject-matter. A private prosecution was brought against the applicants and their conviction of blasphemy was ultimately confirmed by the House of Lords.

The applicants' complaint to the Commission was that their conviction involved violations in particular of Article 10 (freedom of expression), but also of Articles 7 (legality), 9 (freedom of thought and religion) and 14 (anti-discrimination).

Article 10 provides that limitations on freedom of expression must firstly be 'prescribed by law'. The applicants contended that the decision of the British courts that blasphemy is an offence of strict liability, was a creation of the courts and that the limitation had therefore not been 'prescribed by law'. The Commission found that it is acceptable for a Court to interpret and re-state the law within reasonable limits and that the Courts had not overstepped their function in this regard. Secondly the Commission found that the limitation to freedom of expression was to be sought primarily in the protection of the rights of the private prosecutor, Mrs Mary Whitehouse (a well-known moral activist). Since the offence of blasphemous libel had as its main purpose the protection of the 'right of citizens not to be offended in their religious feelings by publications', the Commission concluded that the restriction was indeed covered by a legitimate purpose recognised in the Convention, namely the protection of the rights of others. The Commission also held that the restriction was 'necessary within a democratic society'. The attack against the religious rights of others had attained a certain level of severity and the offence did not seem to be disproportionate to the aim pursued. 
The applicants also contended that the conviction amounted to an unjustified interference with their right to freedom of thought and religion. The Commission, however, found that it had not been substantiated that the publication of the poem in question constituted the exercise of a religious or other belief protected by article 9 of the Convention.

The last point raised by the applicants was that they were discriminated against in terms of Article 14 of the Convention in the exercise of their right to freedom of expression. The Commission held that there was no indication on the facts of the case to support their allegation that they were singled out for restriction on account of their homosexual views, or on account of beliefs not shared by confessing Christians. The poem, the Commission held, was restricted only because of its blasphemous character and for no other reason. Nothing suggested that it would not have been restricted in exactly the same way if it had been published by persons without homosexual tendencies, and with other views on the Christian doctrines. The Commission also held that the applicants could not complain of discrimination because the law of blasphemy protects only the Christian, but no other religion. 'This distinction in fact relates to the object of legal protection, but not to the personal status of the offender'.

The next application before the Commission concerned the decision by English Courts that Salman Rushdie and the Viking Penguin Publishing Company could not be prosecuted for blasphemy, since English law does not extend to religions other than Christianity. The applicant, Choudhury (Choudhury application, 17439/90), a Muslim and a British citizen, complained to the Commission that the United Kingdom had not given the Muslim religion protection against abuse or scurrilous attack, and that without that protection there would inevitably be a limited enjoyment of the right to freedom of religion provided for by Article 9 of the Convention.

The Commission noted that the applicant sought to have a prosecution brought against Rushdie and Penguin in order to vindicate his claim that the book amounted to a scurrilous attack on, inter alia, his religion. He did not claim, and it was clearly not the case according to the Commission, that any State authority or any body for which the United Kingdom Government may be responsible under the Convention, directly interfered in his freedom to manifest his religion or belief.

The Commission also found no indication, in the case before them, of a link between freedom from interference with the freedoms of thought, conscience or religion as guaranteed in Article 9 of the Convention. This part of the complaint was declared incompatible ratione materiae with the provisions of the Convention.

The applicant also alleged that the approach of the British Courts violated Article 14 of the Convention which prohibits discrimination on grounds such as religion, opinion or belief. The Commission held that having found the application incompatible 
ratione materiae with the provisions of Article 9, the complaints under Article 14 also fell to be regarded as incompatible ratione materiae.

Once again, a complaint against the United Kingdom was declared inadmissible and the matter was therefore not referred to the Court itself.

The Rushdie decision of the Commission has been criticized (Poulter 1991:371). However, when one reads the Lemon and Rushdie denials together, it is clear that the accent does not fall on the object protected by an offence, but on the question whether the rights of the individual concerned had been interfered with in an unreasonable manner.

\section{SHOULD THE PROTECTION OF RELIGIOUS FEELINGS BE WIDENED?}

It is submitted that the offence of blasphemy is not unconstitutional as such. It does not discriminate against accused who are charged under it. However, Parliament should launch an inquiry into the possible broadening of the offence to include the religious convictions of all other sections of the population.

It is noted that the majority of the members of the British Law Commission recommended in 1985 (The Law Commission - Criminal Law: Offences against Religion and Public Worship, London 1985) that the offence of blasphemous libel should be repealed. The minority, however, recommended that the offence be extended to cover scurrilous attacks against all recognised (listed) religions (the minority consisted of the chair, Justice Gibson and Brian Davenport, Q.C.).

In South Africa it has also been proposed that the offence of blasphemy be repealed (Labuschagne 1986:434). Blasphemy as criterion has also been left out of the Film and Publication Bill 1995 published in March 1995 and it is unlikely that Parliament will not accept this proposal by the Task Group which formulated the Bill. The Task Group expressly left open the question whether blasphemy, as common law offence, is unconstitutional; it in fact took note of the two decisions of the European Commission of Human Rights discussed above (Report of the Task Group Film and Publication Control, Pretoria 1995, $\S 3.10$ and 8.4.9). The Task Group, however, felt that it would be discriminatory for Parliament to grant special protection to the Christian and Judaic feelings in the new Act. The Task Group introduced a new criterion of 'promoting hatred against the religious convictions of a section of the population'. It rejected the Publications Act's criterion of 'offensive' as subject to subjective interpretation and too uncertain to meet the requirement of 'limited by law of general application' in section 33(1) of the Constitution. Although the Task Group expressed caution in adopting the criterion of 'promoting religious hatred', it could at least base its approach on Canadian, Irish and Northern Irish statutes in this regard (Ibid). Since these statutes 
are criminal statutes and intent is required by them, the Task Group opted for a general exemption of bona fide art and literature as well as bona fide religious or other opinion concerning religion, when the structures, which they propose, apply the said criterion in a quasi-judicial inquiry.

\section{CONCLUSION}

My conclusion is therefore that blasphemy cannot be found to be unconstitutional as a result of its limited sphere of application. It does not discriminate against an accused in the sense that it does nog apply to men but to women only, or that it is only applicable to non-believers. However, Parliament will have to take a policy decision on the matter: blasphemy law only protects the feelings of Christians and Jews and this goes against the spirit of equality. Parliament must therefore either scrap the blasphemy law, which would, to my mind be an unwise step to take, given the sensitivities in this regard or it must scrap the offence of blasphemy and introduce a law which would protect all religious sections against scurrilous attacks. It is submitted that the 'wilful promotion of hatred against a religious section' would be the only acceptable offence. The State would be able to prove that it has a real and pressing interest in religious peace, in the same manner as it has a real and pressing interest in racial peace. It would be unwise to revert to the standard of 'offensive to religious convictions' (as in section 47[2] [b] of the Publications Act 1974) ${ }^{1}$ which amounts to an extremely vague standard. It is submitted that it would not be acceptable as a legal limit as a result of its uncertainty. Although the European Court of Human Rights (Sunday Times v United Kingdom 2 E H R R 1979, §47) has recognised that it is impossible to be absolutely precise in many and especially this area of the law, 'offensiveness' bears the germ of its own destruction in its susceptibility for misuse and varied interpretation.

\section{Endnote}

${ }^{1}$ Several works have been banned under this paragraph, only to be unbanned within a decade or less: the film Jesus Christ Superstar, unbanned in Publications Appeal Board case 82/1983; the novel Kennis van die Aand banned by the Supreme Court in Buren Uitgewers $v$ Raad van Beheer oor Publikasies 1975(1) SA 379 (C), unbanned by the Appeal Board case 131/1981; Magersfontein, $O$ Magersfontein! banned by the Appeal Board in 1977 and unbanned in case 7/1980; Donderdag of Woensdag banned in 1978 and unbanned in case 27/1983. The Last Temptation of Christ (film) and Rushdie's novel Satanic Verses remain on the banned list; the former has not been submitted for review since its banning in 1988 and the appeal to the Appeal Board on the latter was withdrawn. 


\section{Works consulted}

Burchell, J \& Milton, J 1991. Principles of Criminal Law.

Poulter S 1991. Towards legislative reform of the blasphemy and racial hatred laws.

Public Law 13, 371. 